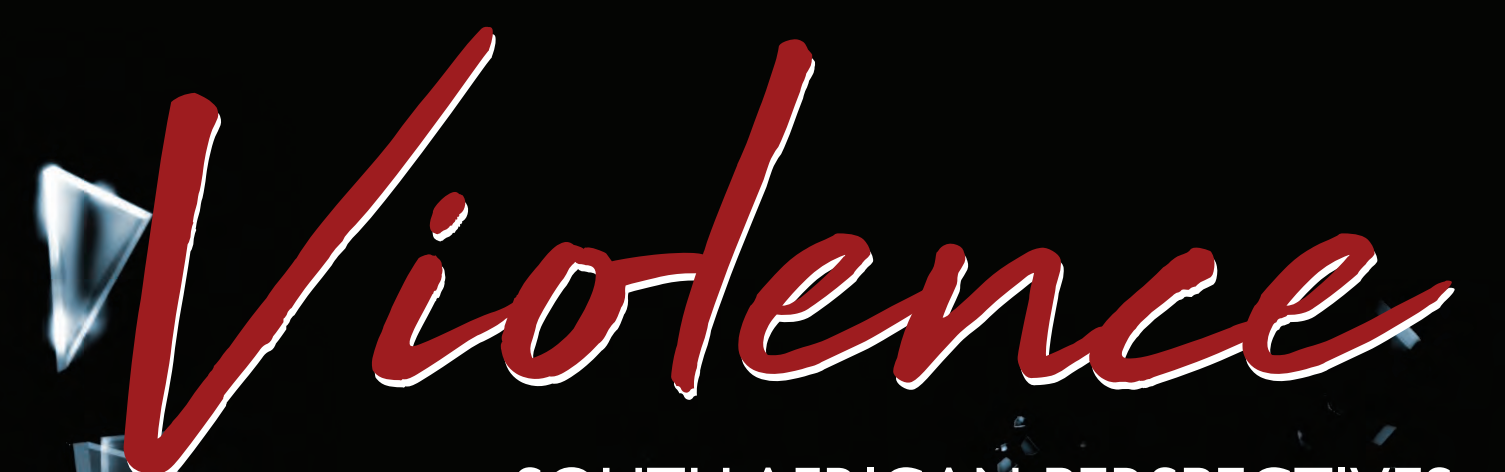

SOUTH,AFRICAN PERSPECTIVES

$\rightarrow$

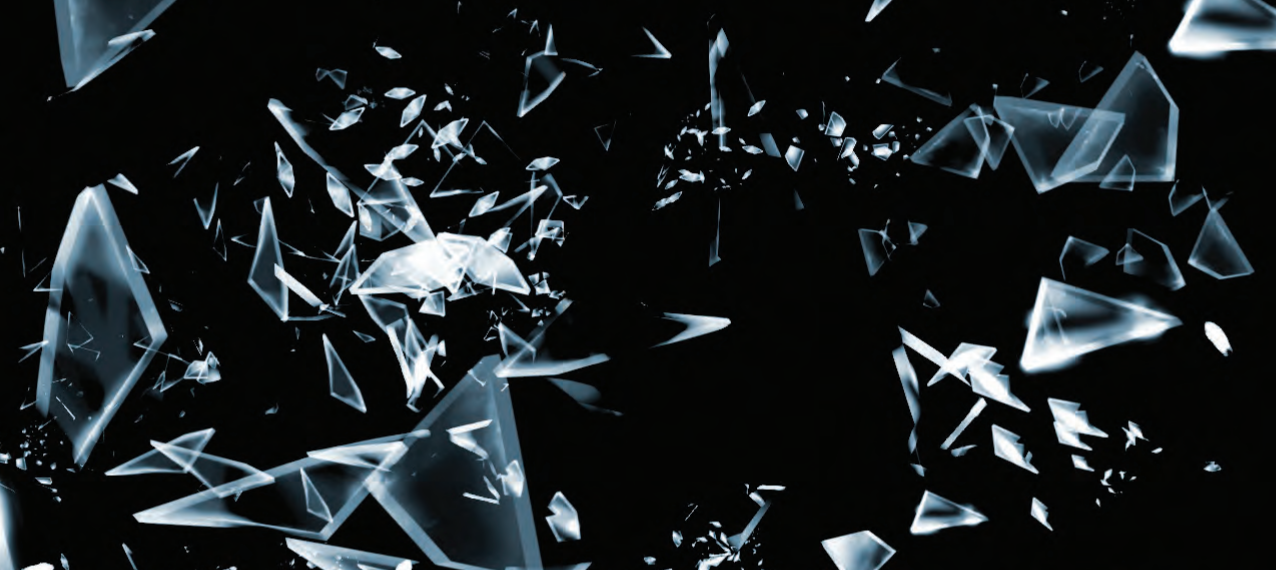

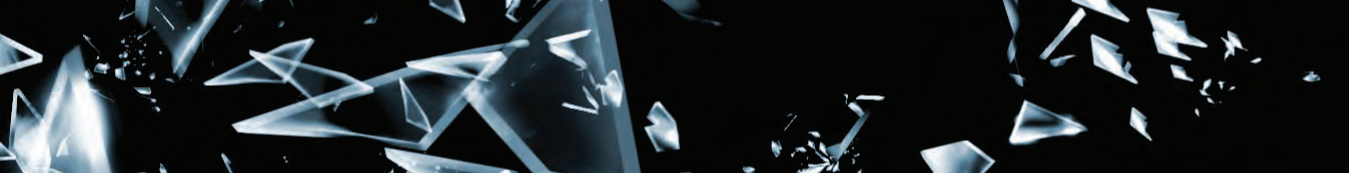

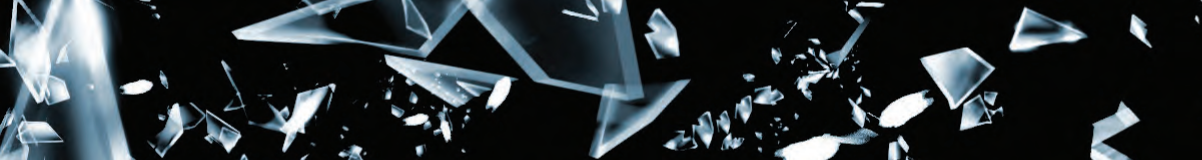

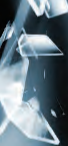

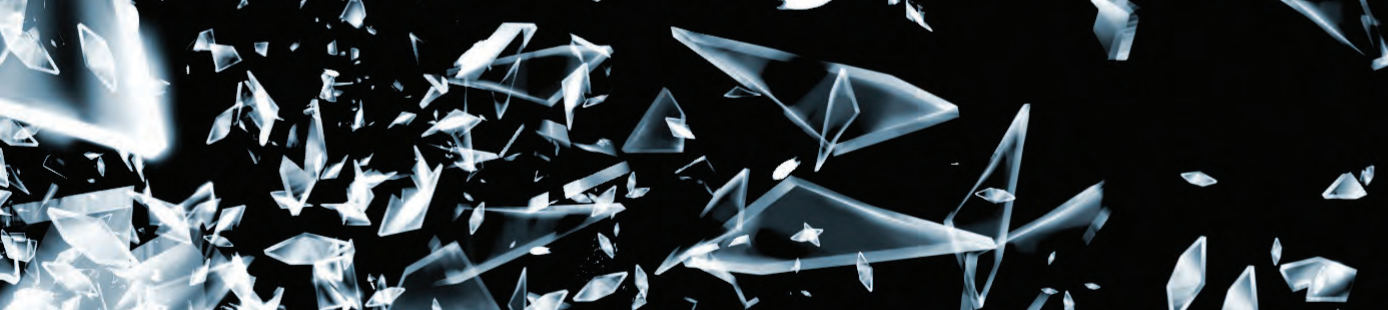

.

a 140

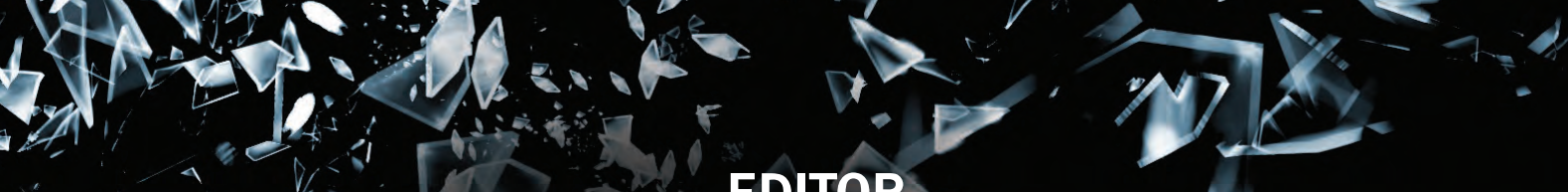

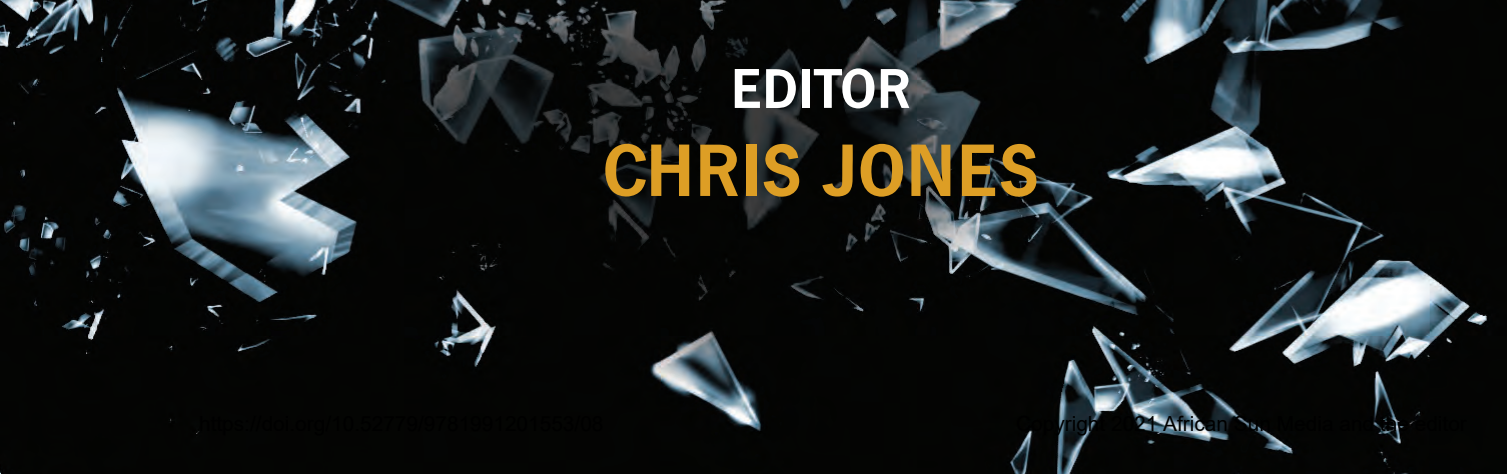




\section{THE VIOLENCE OF NEOLIBERAL CAPITALISM}

Bert Olivier

\section{Keywords}

capital; disaster capitalism; ecology; indebtedness; Lacan's "real"; neoliberalism; poverty; The Shock Doctrine

\section{INTRODUCTION: WHAT IS NEOLIBERAL CAPITALISM?}

To be able to make sense of the claim, implicit to the title of this chapter, that neoliberal capitalism somehow has violent effects, one has to understand what this specific incarnation of capitalism is. Historically, it is related to economic liberalism which, in turn, is related to its political counterpart; hence the term 'political economy' - after all, economic processes and relations have an unavoidable political flipside, which explains why economic issues weigh so heavily on elections. The classic statement of political 'liberalism' (even if the word was not yet used) - that is, the doctrine that individual rights are based on 'natural law', or reason - goes back to John Locke in the late 17th century, for whom the individual, and not the monarch or the family, was primary when considering "the universal principles of politics" (Baumer 1977:107).

Almost a century later, Adam Smith formulated its economic liberal counterpart in The Wealth of Nations (1776) with the argument that, economically, society can do with minimal government interference, because - although individuals typically labour for their own economic benefit, society as a whole benefits from it in the end. This is Smith's doctrine of the so-called "invisible hand" (1776), which is really a manifestation of the era's beliefs in universal natural laws (hence its character as laissez-faire or 'leave alone' economics) - in this case, a 'natural economic law' of sorts - which would ensure the economic well-being of society despite the egocentric tendency of individuals to work primarily for their own enrichment (Baumer 1977:178-179, 226). It is striking that Smith believed that this state of affairs was best achieved with minimal government interference, which is also one of the precepts of neoliberal capitalism (or neoliberalism). Against this backdrop, it is easier to understand what the neoliberal variety of capitalism amounts to. David Harvey provides a succinct account of it (2005:2):

Neoliberalism is in the first instance a theory of political economic practices that proposes that human well-being can best be advanced by liberating individual entrepreneurial freedoms and skills within an institutional framework 
characterised by strong private property rights, free markets, and free trade. The role of the state is to create and preserve an institutional framework appropriate to such practices. The state has to guarantee, for example, the quality and integrity of money. It must also set up those military, defence, police, and legal structures and functions required to secure private property rights and to guarantee, by force if need be, the proper functioning of markets.

Furthermore, if markets do not exist (in areas such as land, water, education, health care, social security, or environmental pollution) then they must be created, by state action if necessary. But beyond these tasks the state should not venture. State interventions in markets (once created) must be kept to a bare minimum because, according to the theory, the state cannot possibly possess enough information to second-guess market signals (prices) and because powerful interest groups will inevitably distort and bias state interventions (particularly in democracies) for their own benefit.

Robert McChesney's (1999:7) account is more concise, but it is noteworthy that it emphasises the control of social life by a comparatively small number of (parties with vested) "interests" - not for the benefit of society at large, but instead for their personal gain: "Neoliberalism is the defining political economic paradigm of our time - it refers to the policies and processes whereby a relative handful of private interests are permitted to control as much as possible of social life in order to maximize their personal profit."

The conventionally smug and historically uninformed amongst us would probably find McChesney's gloss on neoliberalism completely unobjectionable, although it is phrased in terms that should evoke perplexity, if not outright dismay. After all, far from generally being seen as a system that allows the monopolistic control of social life (as McChesney claims) to most people, it is simply the 'normal' state of economic affairs, and is accepted as such (hence the phrase, 'the tyranny of the status quo'). Such uninformed people would probably also find Harvey's characterisation of neoliberalism quite acceptable insofar as it is likely to appeal to their sense of entitlement to 'individual freedom' (which is here, needless to stress, construed primarily as economic freedom), undeterred by government interference. Harvey's (2005) (and McChesney's [1999]) use of the phrase "political economic practices" confirms what was pointed out earlier regarding the commonly used phrase, 'political economy'- no economic freedom can be divorced from political freedom. Harvey (2005) also highlights the vulnerability of the "commons" - "land, water, education, health care, social security, or environmental pollution" - to the predatory incursions of neoliberalism.

The inseparability of the economic and the political is further apparent in another important document of neoliberal thinking - Milton Friedman's Capitalism and Freedom (1962) where he singles out all the characteristics of neoliberalism listed by Harvey. Friedman claims that his stance deserves the appellation of "liberalism" 
(Friedman 1962:12-14) in the 19th century sense of the term, designating a belief in "freedom as the ultimate goal and the individual as the ultimate entity in the society" (ibid:12), in the context of economic laissez-faire or the severe reduction of the role of the state in economic affairs. He claims that, when markets are left unfettered by the state, it would create optimal economic conditions for everyone concerned, from business owners to workers.

With these grandiose claims by the champions of neoliberalism in mind, it may come as a disillusionment of sorts to observe the present economic state of the world, starting with the United States (US) as mainstay of neoliberalism. McChesney's view is incontrovertibly verified by a respectable commentator such as Rana Foroohar, a business and economic journalist working for TIME magazine. Not too long ago she published a book called Makers and Takers (2016a) in which she makes the disconcerting announcement that market capitalism in the US is "broken". In a synoptic article in TIME (2016b), she sets out her reasons for this claim. Having enumerated the "prescriptions" (ibid) for resolving the economic crisis, advanced by the candidates in the 2016 US presidential election - from Trump's desire to increase tax of hedge fund managers, through Sanders's intention to unbundle the big banks, to Hillary Clinton's goal to reinforce financial regulation (2016b:24). Foroohar writes:
All of them are missing the point. America's economic problems go far beyond rich bankers, too-big-to-fail financial institutions, hedge-fund billionaires, offshore tax avoidance or any particular outrage of the moment. In fact, each of these is symptomatic of a more nefarious condition that threatens, in equal measure, the very well-off and the very poor, the red and the blue. The U.S. system of market capitalism itself is broken ... To understand how we got here, you have to understand the relationship between capital markets - meaning the financial system - and businesses.

Foroohar then sets out to explain this relationship, and it gives one a good idea of the present state of neoliberal discourse (which differs conspicuously from its characterisation by McChesney and Harvey above) that she criticises so severely. Homing in on the culprit, she concludes that (2016b:25):

\begin{abstract}
America's economic illness has a name: financialization ... It includes everything from the growth in size and scope of finance and financial activity in the economy; to the rise of debt-fueled speculation over productive lending; to the ascendancy of shareholder value as the sole model for corporate governance; to the proliferation of risky, selfish thinking in both the private and public sectors; to the increasing political power of financiers and the CEOs they enrich; to the way in which a 'markets know best' ideology remains the status quo. Financialization is a big, unfriendly word with broad, disconcerting implications.
\end{abstract}

What she writes here about "debt-fueled speculation" (ibid) will prove highly significant when the issue of debt is addressed below. A brief reconstruction of the prior historical events shows what has led to the present state of affairs since the 
gradual abandonment of the regulation of banks, which "had served America so well" (ibid:25) after the Depression (notably also triggered by financial speculation), to the slowing of the economy in the 1970s. Instead of making difficult decisions about ways of boosting the economy during this time, this responsibility was neatly shifted to the financial markets by politicians. Combined with more "Reaganomic" deregulation that eventually resulted in "loose monetary policy", she shows that this had "unintended consequences" (ibid:25). As a result, the US economy is "chronically dependent on near-zero interest rates to keep from falling back into recession" today (ibid:25). Summarising the consequences of the hegemonic reign of current neoliberal discourse, where financialisation is dominant, Foroohar identifies a number of symptoms of this regrettable state of affairs (ibid:25):

\begin{abstract}
This sickness, not so much the product of venal interests as of a complex and long-term web of changes in government and private industry, now manifests itself in myriad ways: a housing market that is bifurcated and dependent on government life support, a retirement system that has left millions insecure in their old age, a tax code that favours debt over equity. Debt is the lifeblood of finance; with the rise of the securities-and-trading portion of the industry came a rise in debt of all kinds, public and private. That's bad news, since a wide range of academic research shows that rising debt and credit levels stoke financial instability. And yet, as finance has captured a greater and greater piece of the national pie, it has, perversely, all but ensured that debt is indispensable in maintaining any growth at all in an advanced economy like the U.S., where $70 \%$ of output is consumer spending. Debt-fueled finance has become a saccharine substitute for the real thing, an addiction that just gets worse.
\end{abstract}

The theme of this chapter - the 'violence' of neoliberalism - surfaces here where it becomes evident that the financial sector only really serves itself, instead of society at large. One tell-tale sign of this is the sharp decline in banks' lending to small business (that is, refusing to assist ordinary people financially), as well as the disgraceful practice of "share buybacks" (ibid:27). This means that companies purchase their own shares, "often as a way of artificially bolstering share prices in order to enrich investors and executives paid largely in stock options". Astonishingly, in an economy predicated on generating wealth for society at large (as Adam Smith understood liberal capitalist economics) - in other words, for all working citizens, even if this would not be in equal proportion - this tendency has increased to the point where top companies now spend \$1 trillion (USD) annually on dividends and buybacks (about 95\% of their earnings), "rather than investing that money back into research, product development or anything that could contribute to long-term company growth" (ibid:27). In other words, there is not even an attempt to disguise the efforts to enrich shareholders and executives, rather than serving society or citizens in general.

Is it at all surprising, then, that voices highly critical of capital (such as Foroohar's) are being heard in the bosom of capitalist society itself? Notably, the upshot of her criticism is that the current version of "financialist" (ibid:27) neoliberal discourse 
can be identified as an extreme development of its earlier versions as summarised by Harvey and McChesney; it has clearly taken "social control" to an extreme in terms of what Foroohar calls "financialization" (ibid:27) (which manifested itself unmistakeably in the 2008 financial crisis; for a sustained investigation of the link between the housing market, finance, and this crisis, see Harvey [2010], in particular pp.1-39). Recall the inseparability of the economic and the political spheres evident in both Harvey and McChesney's depiction of neoliberalism; in light of this, what Foroohar has highlighted could not be without political consequences in the long run.

This may already be perceived in the public's disenchantment with politicians, evident in the 2016 American presidential race - the fact that millions of Americans supported a maverick like Bernie Sanders and a "businessman" like Donald Trump testifies to their lack of trust in the "political classes" (Von Drehle 2016; Taylor 2016; Altman 2016). Furthermore, sociologist Manuel Castells maintains that this is a worldwide trend. In an interview conducted in the wake of the 2008 financial calamity, he states plainly that, according to what his research has revealed, today, people increasingly do not trust politicians and banks/bankers any longer (more on this below) (Castells 2012:4). From this it is clear that neoliberal practices have had a deleterious - if not economically 'violent' - impact on people's ability to survive economically. As shown above, the reasons for this are addressed by Foroohar and others, such as Harvey (2010).

\section{MANIFESTATIONS OF NEOLIBERAL VIOLENCE: HARDT AND NEGRI}

If what is thematised here as 'violence' on the part of neoliberalism comes across in a comparatively muted manner in the preceding discussion, it is uncovered in its true colours in several areas of research. These include the work of Michael Hardt and Antonio Negri (on which I shall focus first), Gilles Deleuze, Joel Kovel, Slavoj Žižek, Manuel Castells, and Naomi Klein. The duo of Hardt and Negri became philosophical household names with the publication of Empire (2001), the first of a trilogy (its sequels being Multitude [2005] and Commonwealth [2009]), in which they identified the "sovereign power" ruling the contemporary world as an "imperial" (Hardt \& Negri 2001) conglomerate exercising its hegemonic force at the economic, political, juridical, cultural, social, and technological levels. While these texts are all worth considering at length regarding neoliberal 'violence' - "Empire" being their nickname for what I call neoliberalism here - I shall here concentrate on Multitude and a much shorter, but critically trenchant text, Declaration (2012), to foreground their diagnosis of the violence at the (non-)heart of neoliberalism.

In Multitude (2005:xiii-xiv), Hardt and Negri summarise the consequences of living under "Empire" as follows: “...Empire spreads globally its network of hierarchies and divisions that maintain order through new mechanisms of control and constant conflict." This already suggests sustained levels of violence in this 'new world order'. 
However, this is no reason to despair, they argue, because globalisation also gives rise to a new "commonality", or what they call "multitude" (ibid:xiv): “... an open and expansive network in which all differences can be expressed freely and equally, a network that provides the means of encounter so that we can work and live in common." Despite "multitude" denoting such a global network, this has not had the effect of diminishing suffering under neoliberalism, however; on the contrary. Hardt and Negri (ibid:268-288) discuss a number of "global demands for democracy" in the contemporary world, which have been increasing in strength, and considering that this was 15 years ago, the underlying reasons for these demands are even more conspicuous today. These worldwide demands, which assume the guise of protests against the global neoliberal political and economic system, can be understood as an indication that "democracy cannot be made or imposed from above" (ibid:237).

The three principal elements, which recur constantly in all the global protests in question as preconditions for democracy, are (ibid:269-270): “...the critique of existing forms of representation, the protest against poverty, and the opposition to war". It is important to keep in mind that these grievances are responses to different embodiments of violence, the first two of which are structural, although they have concrete, often violent effects during the suppression of protests. Moreover, they are intimately linked to what Hardt and Negri (ibid:232-238) regard as an increasingly obsolete political conceptual framework and vocabulary which were engendered during the birth of modernity, and which can progressively be perceived as having little relevance for the requirements regarding democracy in the globalised, postmodern world.

This pertains to, amongst other things, voting for representatives, and from their further elaboration on this, it becomes apparent that "failures of representation ... increase geometrically in the processes of globalization" (ibid:271). Because of the political structures of globalised "hierarchical interconnectedness", decisions made by national political leaders (whose actions are intertwined with neoliberal economic considerations) - such as Donald Trump and Jair Bolsonaro - have cratological effects on people across the world who are not even (supposedly) represented by them. It often happens that these effects assume different shades of violence, such as when Trump reversed important, ecologically sensitive laws in the US and Bolsonaro did the same in Brazil on economic grounds; in both these cases, the consequences of such actions are arguably deleterious for people and other living beings, not merely in their own countries, by globally, given the interconnectedness of eco-subsystems in the overarching ecosphere. In the case of large multinational corporations with immense global economic power, in relation to world populations, this is equally true, especially because they often 'get away with murder', literally, as well as figuratively. This is demonstrated by Joel Kovel (2007:28-38) with regard to the disastrous industrial accident in Bhopal, India, and the ironic fact that the company 
(Union Carbide) responsible for the loss of thousands of lives through its negligence actually profited from it in the end when the company shares rose on news that the settlement with India amounted to far less than this country had initially demanded. In cases such as these, people have hardly any recourse for registering grievances when they suffer the violent effects of decisions and neglects on the part of politicians and corporations. Ironically, international institutions like the World Bank and the International Monetary Fund (IMF), which putatively represent the economic interests of everyone in the world, do not mitigate the violence accompanying this obvious lack of representation - in the sense of "representation of the world population's best interests" - either, given their economically "dictatorial" practices, let alone the proportionally greater control wielded through them by their wealthy nation-state members (Hardt \& Negri 2005:271-272).

The second set of grievances discussed by Hardt and Negri (ibid:277-282) - those against poverty, or "economic grievances" - are, according to them, "perhaps the most vocal and evident". Nor can these grievances be separated from economic violence perpetrated against the majority of the world's population. Their remark (ibid:278), that "[h] unger and poverty have always been and continue to be today the world's most powerful grievances", must be seen in this light. This becomes clearer when considering the parallel that Hardt and Negri draw between 18th century France and the contemporary world, keeping in mind that today, as then, the gulf between the rich and the poor is enormous, as succinctly captured in the phrase that emanated from the Occupy movement, namely "the 1\% and the 99\%". They highlight the socio-political significance of the more than 40000 "lists of grievances" (cahiers de doléances) compiled all over France and submitted to Louis XVI just before the French Revolution of 1789, and that of the accumulating lists of comparable grievances or protests of the present era (ibid:269). The above may seem like a far-fetched claim, and yet, the evidence they point to is overwhelming and shocking (ibid:278):

The World Bank reports that almost half of the people in the world live on under two dollars a day and a fifth on less than a dollar a day. Such figures are really only a very partial, indirect indication of the state of poverty; real misery is a biopolitical fact that depends on all facets of life and cannot be measured in dollars ... The construction of the global market and the global integration of the national economies has not brought us together but driven us apart, exacerbating the plight of the poor.

Joel Kovel (2007:1-5), too, emphasises the point that, during the decades since 1970, global economic growth has outstripped all previous economic growth. Nevertheless, giving the lie to the oft-repeated claim that, when capitalist wealth is created, the "trickle-down effect" will benefit everyone, instead of contributing towards the eradication of world-poverty, the chasm separating the wealthy and the penniless has recently widened considerably (as several other authors have also observed, 
e.g., Verhaeghe 2014; but see Piketty [2014:8-31] for the varying, unpredictable mechanisms involved in this process). This is the case within specific countries, as well as between wealthy and poor nations. Ironically, the statistics that he and others have provided has not significantly changed the economic situation of the world's impoverished people.

There is no shortage of protests against the "economic violence" visited upon ordinary people by neoliberal capitalism across the world (Hardt \& Negri 2005:278-279); the most significant of these probably being those that object against the "systemic reproduction of poverty", for instance, through foreign debt obligations. Concerning such debt, it is instructive to note that Hardt and Negri (ibid:247-249) differ from Thomas Jefferson who, in the late 18th century, claimed that the so-called Shay's debtors' rebellion in America (which had led to farmers being prosecuted and, in some cases, executed) "refreshed" the "tree of liberty" with "patriots' blood". Instead, they argue that a contemporary counterpart of the Shay's debtors' rebellion on a global scale - even if this were justifiable, in light of the systematic reproduction of debt by poverty and misery - would go hand in hand with colossal, unnecessary destruction and violence. Rather, they point out (ibid:249): "We would be much better served by searching for other means to address the systematic inequalities and contradictions of our global system before any such violent event arises."

The grounds for grievances about unequal economic empowerment pertain inter alia to markets, together with finance (ibid:280-282) and privatisation (ibid:280), which generate wealth through ownership for the few at the cost of the many. The domain of finance has grown prodigiously in power with the globalisation of markets and given the abstractness of financial instruments, such as futures and derivatives, entire sectors of an economy can be affected favourably or adversely overnight, violently affecting the concrete lives of people. Therefore, what protesters hold against these far-reaching financial-economic practices, is their ability to affect the economic conditions of entire populations negatively while benefitting the few who are the 'players' of the financial markets, concentrating wealth in the hands of a small minority. International entrepreneur, Nick Hanauer (2014), confirms the existence of such worrying economic inequality in relation to himself and his fellow "zillionaires" in no uncertain terms. (That this is an instance of neoliberal violence becomes clearer in the light of the work of Slavoj Žižek [2008] on violence, discussed below).

Hardt and Negri home in on the relation between economic disempowerment and the "rule" of neoliberalism where they address the contemporary "figures of subjectivity" in Declaration (2012). These figures are all related to neoliberal power in so far as they function as mechanisms to ensure the compliance, or "docility" (to borrow a term from Michel Foucault), of subjects under neoliberal rule. Hardt and Negri introduce these as follows (2012:14): 
The triumph of neoliberalism and its crisis have shifted the terms of economic and political life, but they have also operated a social, anthropological transformation, fabricating new figures of subjectivity. The hegemony of finance and the banks has produced the indebted. Control over information and communication networks has created the mediatized. The security regime and the generalized state of exception have constructed a figure prey to fear and yearning for protection - the securitized. And the corruption of democracy has forged a strange, depoliticized figure, the represented.

Their elaboration on these modes of subjectivity leaves no doubt that they have been violently engendered by the system in question. Of these, the figure of "the indebted" (the most pertinent of the four) is related to Gilles Deleuze's (1992) elaboration on the character of what the latter saw as the novel form of power which succeeded what Foucault (1995) had thought of as "societies of discipline", namely "societies of control" - a description that fits neoliberalism like a glove. Deleuze displays his prescience where he alludes to debt as a highly efficient mode of social control (1992:6-7):

Control is short-term and of rapid rates of turnover, but also continuous and without limit, while discipline was of long duration, infinite and discontinuous. Man is no longer man enclosed, but man in debt. It is true that capitalism has retained as a constant the extreme poverty of three quarters of humanity, too poor for debt, too numerous for confinement: control will not only have to deal with erosions of frontiers but with the explosions within shanty towns or ghettos.

Of "the indebted", Hardt and Negri state (2012:14-15) that being indebted has become "the general condition of social life", given the virtual impossibility for the vast majority of people to avoid incurring debt, whether it is a student loan or a house mortgage. It sounds shocking that, as they phrase it, the "social safety net has passed from a system of welfare to one of debtfare". And the worst is that one's "subjectivity is configured on the foundation of debt", as evidenced from the fact that, today, debt exercises a moral force through "responsibility and guilt". Just how violently neoliberalism transforms people from those capable of happiness to those mired in the misery of indebtedness is apparent where they write (ibid:15): "Little by little, the pleasures of activity and creation are transformed into a nightmare for those who do not possess the means to enjoy their lives. Life has been sold to the enemy." Succinctly put, under neoliberalism, social life is financially controlled.

As a result, Hardt and Negri (ibid:17) remind one, the meaning of "the poor" has changed - this social category no longer encompasses only the unemployed and precarious, part-time workers, but also stable, wage-earning workers and what they call "the impoverished strata of the so-called middle class", whose poverty manifests itself mainly as "chains of debt". The violent effects of this fraught mode of existence is apparent from the number of suicides in neoliberal societies (see for example Wang, Wright \& Wakatsuki 2020; Klein 2007:238-239). One may be puzzled by this power 
that "debt" has over people's lives (and deaths). After all, it goes back to the financial basis of contemporary society - that is, to capital, whose strange, almost uncanny power is addressed via the work of Slavoj Žižek, below.

\section{ŽIŽEK ON CAPITAL AND NEOLIBERAL VIOLENCE}

In On Violence, Žižek (2008:12-13) uncovers the relationship between the abstract "dance" of capital and the concrete world of human existence and suffering. What he calls "objective violence" has to be historicised, he writes, because it has assumed a novel guise with capitalism. He reminds his readers that Marx already depicted the crazy, perpetually self-augmenting circulation of capital, and that it has culminated in the financial sphere of the present (discussed above with reference to the work of Foroohar) where speculation on so-called "futures" exemplifies capital's endless "parthogenesis" (Žižek 2008) - that is, unaided self-reproduction - in relation to a temporal dimension that is, precisely, not yet actualised. Žižek warns against the overly simplistic image of capital as a kind of growing monstrosity that travels along its own trajectory regardless of human or ecological costs, and indifferent to the natural resources and real, productive people on which it feeds and depends.

Here, Žižek has recourse to the Lacanian psychoanalytic notion of the 'real' to explain the far more insidious relation of capital (which has finally been 'freed' by neoliberalism by cutting the moorings of capital to the world of material production) to the concrete social world. To understand what he writes in the excerpt quoted below, one has to recall that Lacan (1981) distinguishes amongst three "registers" of human subjectivity: the "real" (which surpasses symbolisation, or language); the "imaginary" (the register in which one's sense of an identifiable "self" or "ego" is inscribed); and the symbolic (language as "discourse", that is in so far as language articulates power relations). The latter two, together, constitute what we commonly call "reality" (which is linguistically describable and concretely sensed as "image" in space and time), and is not at all the same as the enigmatic "real" (ibid) which, as already remarked, cannot be iconically depicted, nor linguistically grasped. The important point is that although the "real" marks the "internal" limits of language, it has "effects" in symbolically appropriated "reality", for example in the case of a traumatic experience which affects the subject profoundly; while it is impossible to "get a grip" on the traumatic event in language it remains a "missed encounter" (Lacan 1981:53-55; Olivier 2004, 2005).

Similarly, to return to the question of neoliberal capitalist violence - notwithstanding the 'abstract' character of capital, circling the globe in the virtual realm, it has concrete effects on human (and other) lives. Žižek points out that, contrary to what may seem to be the case, the frenzy of capital does not proceed from "real-life" contradictions; on the contrary (Žižek 2008:12-13):

Rather his [Marx's] point is that one cannot properly grasp the first (the social reality of material production and social interaction) without the second: it is the self- 
propelling metaphysical dance of capital that runs the show, that provides the key to real-life developments and catastrophes. Therein resides the fundamental systemic violence of capitalism, much more uncanny than any direct precapitalist socio-ideological violence: this violence is no longer attributable to concrete individuals and their 'evil' intentions, but is purely 'objective', systemic, anonymous. Here we encounter the Lacanian difference between reality and the Real: 'reality' is the social reality of the actual people involved in interaction and in the productive processes, while the Real is the inexorable 'abstract', spectral logic of capital that determines what goes on in social reality.

One can experience this gap in a palpable way when one visits a country where life is obviously in shambles. We see a lot of ecological decay and human misery. However, the economist's report that one reads afterwards informs us that the country's economic situation is 'financially sound' - reality doesn't matter, what matters is the ['real'] situation of capital...

Here, one gets as accurate a portrayal as is possible of the "spectral" causality involved in neoliberal capitalist violence: ontologically speaking, today the "real" (Žižek 2008) which determines (in the sense of concretely organising) social and natural reality, is capital, and Žižek does not pull his punches when he insists that ideological obfuscation does not consist in affirming this "causal" link between the virtual realm of capital and concrete social reality, but in pretending that "the stock market is not about mysterious fluctuations, but about real people and their products" (ibid:13). Never mind that these "real people" are usually at the receiving end of such capitalist violence when they protest en masse about harsh austerity conditions accompanying their country's (e.g., Greece) repayment of colossal loans from the European Central Bank, the World Bank or the IMF - such "social unrest" only serves to exacerbate their existential situation of suffering the violence of capital, which manifests itself in unbearable debt, amongst other things (as pointed out earlier).

It should therefore not be surprising that people across the world seem to be turning to different ways of living, given the toll that neoliberal violence takes on their lives. Recall McChesney's characterisation on neoliberalism, referred to earlier (1999:7): "...the policies and processes whereby a relative handful of private interests are permitted to control as much as possible of social life in order to maximize their personal profit". Such control, we have seen, is made possible by the 'real' of capital or perhaps 'as' capital, because capital remains inscrutable despite the many attempts at finding adequate symbols to depict it; money (such as banknotes and coins), for example, while ostensibly being concrete, is just a symbol of 'capital', and even the name 'capital' falls woefully short of capturing its enigmatic being. Small wonder that one of David Harvey's books is titled The Enigma of Capital (2010).

In the face of this unfathomable leviathan encircling the globe, and having experienced the social and economic violence it inflicted upon society during and after the 2008 financial crisis, many people the world over have been forced to alter their way of life fundamentally, including their financial-economic practices. In the BBC interview 
transcript (2012:2-3) on the book (that he and several colleagues published) on the economic effects of the 2008 financial upheaval, Aftermath: The Cultures of the Economic Crisis (2012a), Manuel Castells responds to the interviewer, Paul Mason's question concerning “...this ... new layer of post-capitalist alternative economic activities. How long can that survive?", saying:

Well it's expanding, as a matter of fact. What I refer to is about the observation of one of my latest studies on people who have decided not to wait for the revolution to start living differently - meaning the expansion of what I call in a technical term non-capitalist practices, meaning they are economic practices but they don't have a for profit motivation, such as barter networks; such as social currencies; co-operatives; self-management; agricultural networks; helping each other simply in terms of wanting to be together; networks of providing services for free to others in the expectation that someone also will provide to you. All this exists and it's expanding throughout the world.

The situation described by Castells (the most often quoted sociologist/social theorist in the world) is symptomatic of growing numbers of people being disenchanted and disaffected by the empty promises of the capitalist class, that everyone in society will benefit from the system. It also gives the lie to the oft-cited remark by Margaret Thatcher - later repeated by David Cameron - "There is no alternative" (Klein 2014:56). What Castells depicts here is precisely that there are alternatives to neoliberalism, under the yoke of which people suffer continually (Olivier 2015). Mason follows up with the question, "So where is it going?", to which Castells responds (ibid:3):

\begin{abstract}
You see the issue ... When I mention this alternative economic culture, it's a combination of two things. A number of people have been doing this for quite a while already because they don't agree with the meaninglessness of their lives. But now there is something else - it's the legion of consumers who cannot consume. And, therefore, since they do not consume - they don't have the money, they don't have the credit, they don't have anything - then they try at least to make sense of their lives doing something different. So it's at the same time because of needs and because of values - the two things together - that's why it's expanding. And this has been in the third world for a long time, but it's different. It was survival waiting to be integrated in the system where this is a massive pull-out from the system.
\end{abstract}

One does not have to look far for the reasons behind this "pull-out from the system", which has inflicted so much hardship on people worldwide. When Mason presses Castells to explain why he claims that the present crisis is "cultural", and whether it is "fundamental", Castells's answer is not only far-reaching regarding the cultural changes that are occurring in the face of neoliberal excesses, but also functions as a barometer of the degree to which people have experienced economic violence at the hands of this merciless kind of capitalism (ibid:4):

It is fundamental because it triggers a crisis of trust in the two big powers of our world: the political system and the financial system. People don't trust where they 
put their money and they don't trust those who they delegate in terms of their vote [my italics - B.O.]. All the statistics are there. It's a dramatic crisis of trust and if there is no trust, there is no society. It's simply institutions that still try to control citizens. But the main thing is the acceptance in their minds because nothing else is possible. So what we are not going to see is the economic collapse per se because societies cannot work in a social vacuum.

Castells's insights, based upon global, "ground-level” social research, places Žižek's elaboration on capital as the (Lacanian) "real" (Žižek 2008), with its concrete effects on the lives of people, in a new, more comprehensible light. It is no exaggeration to describe the impact of these effects on human beings as violent in so far as they may assume the guise of being brutally evicted from one's home - as many people were in the wake of the 2008 financial crisis when houses were repossessed by banks where owners could not make mortgage repayments - or harshly cut off from banking benefits like loans. It is such rough treatment at the hands of the agents of capital that forces people to seek a different mode of living, of the kind alluded to by Castells.

\section{NEOLIBERAL "SHOCK"STRATEGIES}

Establishing a connection between neoliberalism and "shock" (Klein 2007) has been the particular contribution by Canadian investigative journalist and fearless activist, Naomi Klein, to the literature in this field. Klein discloses the excesses of the most recent embodiment of capitalism in The Shock Doctrine: The Rise of Disaster Capitalism (2007). This phenomenon, she demonstrates, is impelled by the ideological imperative to privatise every component of an economy when (and while) communities or nations are in a state of shock and disorientation as a result of a collective natural or political trauma. In this far-reaching book, Klein focuses on several such collective traumas which were succeeded by unremitting privatisation. They include the economic effects of South Africa's transition to democracy in 1994, the unsettling consequences of the American invasion of Iraq on the local population (in 2003), the uprooting results of the devastating tsunami along the coast of Sri Lanka in 2004, and the disastrous effects of Hurricane Katrina on the population of New Orleans in 2005.

How was the violence that accompanies neoliberal practices manifested in these traumatising events? Klein (2007:194-217) details how, in South Africa, the population achieved democracy in political terms through negotiations, but simultaneously lost in economic terms as a result of neoliberal conditions imposed on them by international financial institutions, with deleterious economic consequences for poor people. Again, violence has an economic face in so far as there is little that impoverished people can do in the face of a system that is geared to favour those who can participate in its neoliberal rule-governed processes. It resonates with a remark by two of Michel Foucault's doctoral students - referring to the aftermath of a comparable economic transition in 19th century France - which alludes to the fact that citizens, including 
erstwhile peasants, had political and economic rights under the new "democratic" dispensation, but the suffering of the latter did not cease because of "the abstract violences of money" (Peter \& Favret 1982:187).

What further emerges from Klein's (2007:323-382) indefatigable investigations, specifically in Iraq, is that, subsequent to the US military invasion, American companies profited exorbitantly, in contrast with the economic and political hardships endured by the local people. Similarly (ibid:3-21), on the Sri Lanka coast, where the villages of the local fishing communities were destroyed by the tsunami, the land was sold by the government to private development companies, in the process depriving the fishing communities of their source of survival. Adding insult to injury, these entrepreneurs built resorts for the rich where the villages were before. Turning to the aftermath of Katrina in New Orleans (ibid:3-21), the erstwhile, well-functioning public-school system was swiftly replaced by a private, profit-oriented charter school system. As a result, many older (and better-paid), experienced teachers lost their jobs and young teachers were employed at comparatively low salaries and without the additional benefits that teachers had enjoyed in the public school system.

These are all examples of the cynical economic exploitation of opportunities in the wake of political commotions and natural disasters by so-called "disaster capitalism" (Klein 2007), with very harmful economic consequences (such as loss of employment and hence income) for the individuals and communities involved. Klein further (ibid:238-239, 265, 277) elaborates on something that corroborates my contention, that neoliberal capitalism represents a "violent" economic practice, namely, the phenomenon of an escalation of suicide in the context of the expansion of neoliberal practices under conditions of "disaster capitalism". It is generally known that the Great Depression of 1929 witnessed many suicides on the part of people who apparently had no hope that their economic circumstances would improve. From Klein's investigations, it is clear that, under "disaster capitalism" (Klein 2007), suicide has again become a gauge for the psychological effects of economic adversity.

First, she draws attention to Russia where economic "shock therapy" (Klein 2007) (parallel to medical shock therapy which supposedly clears the psyche, or brain, for a "new beginning") was introduced in 1992, three years after the disintegration of the Soviet Union (USSR). The number of suicides in Russia went up almost immediately, so much so that the 1994 statistics were almost double of what it had been eight years earlier. Simultaneously, violent crime more than quadrupled compared to what it had been. Vladimir Gusev, cited by Klein (ibid:238), observed in 2006 that the previous years of "criminal capitalism" had reduced the Russian population by $10 \%$. If anything, things were even worse in South Korea around 1997 - the period of what was cynically branded the 'Asian Flu'. The incidence of suicide increased by no less than 50\% in 1998 amongst South Koreans, with most of these occurring amongst older parents who, it seemed, committed suicide to lessen the economic hardship of debt on their children. 
The worst thing about these economic catastrophes is the shocking evidence adduced by Klein, that the IMF and 'Wall Street' purposely adopted a policy of "doing nothing" to help these countries. Unbelievably, it regarded these as opportunities for capitalist expansion instead. The mere fact that Klein dubs these instances of inflicting financialeconomic hardship on people "disaster capitalism" (Klein 2007), already unmistakably signals that there is a certain kind of violence involved.

In This Changes Everything (2014:40-88), Klein goes further along the trajectory she initiated in The Shock Doctrine (2007) regarding continued violence visited upon people. With the advent of humanly manufactured climate change, of which global warming is the most conspicuous manifestation (Foster, Clark \& York 2010:11-15), the wealthy nations of the world are already preparing themselves to make a handsome profit out of "extreme climate events", such as severe, disruptive storms. Conservative climate denialists are apparently not worried about the likelihood that poorer nations will bear the brunt of (mainly) northern hemisphere countries' industrialeconomic contribution to anthropogenic climate change, as evidenced by their view, that countries of the poor south should "adapt" to warmer climates. Furthermore (Klein 2014:69):

In the wealthier nations, we will protect our major cities with costly seawalls and storm barriers while leaving vast areas of coastline that are inhabited by poor and Indigenous people to the ravages of storms and rising seas. We may well do the same on the planetary scale, deploying techno-fixes [see in this regard Olivier 2019] to lower global temperatures that will pose far greater risks to those living in the tropics than in the Global North ... And rather than recognizing that we owe a debt to migrants forced to flee their lands as a result of our actions (and inactions), our governments will build ever more high-tech fortresses and adopt even more draconian anti-immigration laws. And, in the name of 'national security,' we will intervene in foreign conflicts over water, oil, and arable land, or start those conflicts ourselves. In short our culture will do what it is already doing, only with more brutality and barbarism, because that is what our system is built to do.

In other words, one should not be surprised to find that, as the effects of global warming worsen, wealthy nations would "assist" poorer countries by making available "for-profit" peace-keeping companies that they can hire to quell civil unrest and looting. Small wonder that Klein (2014:66) writes about this cynical attitude under the heading, 'Get Rich Off A Warming World'! While there is general agreement that the industrialised nations are historically responsible for global warming - it was in Britain where "the coal-fired steam engine" (ibid:75) was invented, after all - it appears that it will be the nations of the global south that will suffer most under the violent weather unleashed by a violent economic system.

To drive the point home about Klein's (2007) diagnosis of "neoliberal violence", a brief look at her book on Trump has to be added, specifically concerning his and neoliberalism's conspicuous "sadism". Klein (2017:55) reminds one of the reality television 
show (The Apprentice) that made Trump famous, where a number of aspiring young people are mercilessly pitted against one another, with Trump ending every episode addressing the same words to the contender who is eliminated in that particular episode: "You're fired!" The real significance of this "sadistic" behaviour (for the present argument) becomes clearer where Klein, comparing reality shows like the hugely popular Survivor and The Apprentice, writes (ibid:56):

The whole genre - the alliances, the backstabbing, the one person left standing - was always a kind of capitalist burlesque. Before The Apprentice, however, there was at least the pretext that it was about something else: how to survive in the wilderness, how to catch a husband, how to be a housemate. With Donald Trump's arrival, the veneer was gone. The Apprentice was explicitly about the race to survive in the cutthroat 'jungle' of late capitalism ...

Klein does not hesitate to reveal the previously covered-up truth about capitalism either (ibid:58):

What's interesting about this particular piece of televised class warfare, which aired in 2007, is that the pretense sold to a previous generation - capitalism was going to create the best of all possible worlds - is completely absent. No: this is a system that generates a few big winners and hordes of losers, so you'd better make damn sure you are on the winning team.

Trump's use of language in The Apprentice therefore made the violent economic struggle, inseparable from neoliberalism, so obvious that only stupefied viewers could possibly have missed it. What is especially noteworthy here is what Klein (ibid:57) sees as the television show's increasingly "sadistic" character and its "underlying cruelty", concretised (for example) in the divergent accommodation facilities provided to the "winning" and the "losing" team, respectively. The "winners" received every imaginable luxury, like meetings with celebrities and champagne around the pool, while the "losers", dubbed the "have-nots" by Trump, were demoted to staying in tents with no electricity, and getting paper plates to eat from in what was dubbed "Trump trailer park" (ibid:57).

Epitomising the worldview underpinning neoliberalism, that there are only "winners" and "losers", Trump informed the tent-dwellers in one episode that "life's a bitch" (ibid:57). Klein foregrounds the violence of the economic system that is at the root of the conspicuous socio-economic inequalities of contemporary society where she writes (ibid:57): "In other words, Trump and Burnett [producer of The Apprentice] deliberately created a microcosm of the very real and ever-widening inequalities outside the show, the same injustices that have enraged many Trump voters - but they played those inequalities for kicks, turning them into a spectator sport."

In sum, Donald Trump stands as a grotesque metonymy of the economic system known as neoliberalism, embodying its endemic violence, its exploitation, and its thinly veiled sadism. 


\section{CONCLUSION}

Against the backdrop of the preceding, it stands to reason that neoliberalism, which is oriented according to the enrichment of individuals, not the welfare of communities (McChesney 1999; Harvey 2010; Hanauer 2014), will have scant regard for the plight of individuals and communities who do not number amongst what are known today as the "managerial elites" (Castells 2010:445-448), particularly regarding the impact of the current pandemic on the former. A recent pronouncement by Pope Francis sums this up well (Gallagher \& Benveniste 2020):

'The marketplace by itself cannot resolve every problem, however much we are asked to believe this dogma of neoliberal faith', the pope wrote. He added that free-market capitalism 'reproduces itself' by resorting to the magic theories of 'spillover' or 'trickle' as the only solution to societal problems. The pope said this 'spillover' does not 'resolve the inequality that gives rise to new forms of violence threatening the fabric of society'.

I rest my case. 


\section{REFERENCES}

Altman, A. 2016. Tribal Warrior. TIME, 14 March, pp. 26-29.

Baumer, F.L. 1977. Modern European Thought. Continuity and Change in Ideas, 1600-1950. Macmillan: New York.

Castells, M. 2012. Analysis: Alternative Economic Cultures: Manuel Castells. Interviewed by Paul Mason, BBC Documentary transcript, London.

Castells, M. 2010. The Rise of the Network Society. 2nd Edition. Wiley-Blackwell: Malden, MA.

Castells, M., Caraca, J. \& Cardoso, G. (eds.). 2012a. Aftermath: The Cultures of the Economic Crisis. Oxford University Press: Oxford.

Deleuze, G. 1992. Postscript on the societies of control, (October) 59, Winter, pp. 3-7.

Foroohar, R. 2016a. Makers and Takers. Crown Business Publishers: New York.

Foroohar, R. 2016b. Saving Capitalism. TIME Magazine, 23 May, pp. 22-28.

Foster, J.B., Clark, B. \& York, R. 2010. The Ecological Rift: Capitalism's War on the Earth. Monthly Review Press: New York.

Friedman, M. 1962. Capitalism and Freedom. University of Chicago Press: Chicago.

Foucault, M. 1995. Discipline and Punish. The Birth of the Prison. A. Sheridan (transl.). Vintage: New York.

Gallagher, D. \& Benveniste, A. 2020. Pope Francis says capitalism has failed in the pandemic. CNN Business, 4 October. [Online]. https://cnn.it/3GGpOdY [Accessed 4 December 2020].

Hanauer, N. 2014. The Pitchforks are coming ... for us plutocrats. Politico Magazine, July/August. [Online]. https://politi.co/3w 84ZDG [Accessed 4 December 2020].

Hardt, M. \& Negri, A. 2012. Declaration. Argo Navis: New York.

Hardt, M. \& Negri, A. 2009. Commonwealth. The Belknap Press of Harvard University Press: Cambridge, MA.

Hardt, M. \& Negri, A. 2005. Multitude: War and Democracy in the Age of Empire. Penguin: New York.

Hardt, M. \& Negri, A. 2001. Empire. Harvard University Press: Cambridge, MA. https:// doi.org/10.2307/j.ctvjnrw54
Harvey, D. 2005. A Brief History of Neoliberalism. Oxford University Press: Oxford. https://doi.org/10.1093/ oso/9780199283262.001.0001

Harvey, D. 2010. The Enigma of Capital and the Crises of Capitalism. Oxford University Press: Oxford.

Klein, N. 2017. No is Not Enough. Defeating the New Shock Politics. Penguin Random House: London.

Klein, N. 2014. This Changes Everything. Capitalism vs. the Climate. Penguin Books: London.

Klein, N. 2007. The Shock Doctrine. The Rise of Disaster Capitalism. Allen Lane (Penguin Books): London.

Kovel, J. 2007. The Enemy of Nature. The End of Capitalism or the End of the World? 2nd Expanded Edition. Zed Books: New York. https://doi.org/10.5040/9781350251007

Lacan, J. 1981. The Seminar of Jacques Lacan, Book XI: The Four Fundamental Concepts of Psychoanalysis. A. Sheridan. W.W. Norton: New York.

McChesney, R.W. 1999. Introduction. In: N. Chomsky. Profit over People. Neoliberalism and Global Order. Seven Stories Press: New York. pp. 7-16.

Olivier, B. 2019. How not to approach nature: Devlin's Geostorm (2017) and 'blowback'. South African Journal of Art History, 34(3):37-48.

Olivier, B. 2015. Capitalism and suffering. Psychology in Society (PINS), 48:1-21. https://doi.org/10.17159/2309-8708/ 2015/n48a1

Olivier, B. 2005. Lacan and the question of the psychotherapist's ethical orientation. SA Journal of Psychology, 35(4):657-683. https://doi.org/10.1177/0081246305 03500404

Olivier, B. 2004. Lacan's subject: the imaginary, language, the real and philosophy. South African Journal of Philosophy, 23(1):1-19. https://doi.org/10.4314/sajpem.v23i1.31381

Peter, J-P. \& Favret, J. 1982. The animal, the madman, and death. In: M. Foucault (ed.). I, Pierre Riviere, Having Slaughtered my Mother, my Sister and my Brother ... A Case of Parricide in the 19th Century. Bison Books: London. pp. 175-199. 
Piketty, T. 2014. Capital in the 21st Century. Transl. A. Goldhammer. The Belknap Press of Harvard University Press: Cambridge, MA.

Taylor, P. 2016. The Kids are all Left. TIME, 29 February, pp. 22-27.

Verhaeghe, P. 2014. What About Me? The Struggle for Identity in a Market-Based Society. J. Hedley-Prôle (transl.). Scribe Publications: London.
Von Drehle, D. 2016. Destination Unknown. TIME, 14 March, pp. 20-25.

Wang, S., Wright, R. \& Wakatsuki, Y. 2020. In Japan, more people died from suicide last month than from Covid in all of 2020. And women have been impacted most. CNN World, 30 November. [Online]. https://cnn. it/3GRZjCL [Accessed 30 November 2020].

Žižek 2008. On Violence. Six Sideways Reflections. Picador: New York. 